\title{
Paradoxes of Ultra-Vires Review: A Critical Review of the PSPP Decision and Its Initial Reception
}

\author{
Mattias Wendel*
}

(Received 15 July 2020; accepted 16 July 2020)

\begin{abstract}
This contribution explores paradoxes of ultra vires review with specific regard to the PSPP decision of the German Federal Constitutional Court in the light of the decision's initial reception. While some of these paradoxes are inherent in the very nature of ultra vires review, others are specific to the PSPP judgment. They relate to the underlying doctrinal and theoretical premises, to key concepts such as proportionality or the scope of judicial review, to the overall context in which the decision is embedded, and even to the community which is addressed and affected by the decision. It is the sad irony that the Federal Constitutional Court, while accusing others of manifestly exceeding their competences, does not sufficiently adhere to its own standards and increasingly risks overstretching the boundaries of its mandate under the Basic Law.
\end{abstract}

Keywords: PSPP; German Federal Constitutional Court; ultra vires review; judicial review; proportionality

\section{A. Introduction}

Ultra vires review relates to the crossing of borders in at least a triple sense. First, it deals with an alleged transgression of competences. Second, it transcends the border of one legal system, relying on a hybrid standard of review, rooted in national constitutional law, but stretching out far into EU law. Third, it also crosses the border between the normal and the exceptional. It is a safeguard of last resort, a control mechanism intended to keep things in balance by its very existence and in view of the circumstance that it would not normally be applied. It is a difficult creature, a borderline instrument.

With its judgment of May 5, 2020, the German Federal Constitutional Court (FCC) crossed borders when declaring both the judgment of the CJEU in Weiß and the ECB's Public Sector Asset Purchase Programme (PSPP) as partly ultra vires. ${ }^{1}$ Reception was mixed, both in the media and in academic circles. In a way, the debate on the PSPP decision is as revealing as is the decision itself. It is a debate on different aspects at different levels, conducted in different languages-linguistically as well as professionally_and involving actors from various fields, actors who do not rarely talk past one another, be it legal practitioners, scholars, economics, journalists or politicians.

${ }^{*}$ The author is full professor for Public Law, EU Law, International Law, Migration Law, and Comparative Law at Leipzig University.

${ }^{1}$ Bundesverfassungsgericht [BVerfG] [Federal Constitutional Court], Case No. 2 BvR 859/15, (May 5, 2020), at paras. 118-178, https://www.bundesverfassungsgericht.de/SharedDocs/Entscheidungen/EN/2020/05/rs20200505_2bvr085915en. html [hereinafter PSPP].

() The Author(s), 2020. Published by Cambridge University Press on behalf of the German Law Journal. This is an Open Access article, distributed under the terms of the Creative Commons Attribution licence (http://creativecommons.org/licenses/by/4.0/), which permits unrestricted re-use, distribution, and reproduction in any medium, provided the original work is properly cited. 
Affirmative reactions highlighted that the decision would strengthen judicial review, ${ }^{2}$ that its specific vision of proportionality could help clarify factual interferences of competences between the EU and its Member States, ${ }^{3}$ or that it could have the effect of fostering a reform of the EMU. ${ }^{4}$ Others pointed out that the decision had to be seen against the historical background of a continued and repeated expansion of competences on behalf of an allegedly unchained CJEU which, on the basis of an over-constitutionalized EU law, had made "deep breaches" in the legal systems of the Member States over the years. ${ }^{5}$

Critical voices pointed to the disrespect of a binding judgment by the CJEU and the resulting damage for the community of law as a whole, taking into consideration that the decision could serve as a negative role model for other national courts in the current rule of law crisis. ${ }^{6}$ Further critics argued that the FCC had overstepped the mark by accusing the Bundestag and the Federal Government of violating the essence of the principle of democracy by not having taken "suitable" steps against PSPP. ${ }^{7}$ Others criticized the FCC for misconceiving the Treaty provisions on competences and the principle of proportionality, ${ }^{8}$ for misapprehending the interrelation between monetary and economic policy, ${ }^{9}$ for trying to impose a specific (German) approach of judicial review upon all other Member States, ${ }^{10}$ for turning ultra vires review into a mere review of legality as if the FCC was the Supreme Court of the EU, ${ }^{11}$ and ultimately for failing to refer a second preliminary question to the CJEU. ${ }^{12}$

The widespread criticism, also in the media and the political realm, was apparently perceived as so severe that judge rapporteur Huber and President Voßkuhle launched a media offensive, trying to explain the decision in several interviews. ${ }^{13}$ Interestingly, the judgment was also heavily criticized from within the German judiciary, most prominently and fiercely by a Presiding Judge at the

\footnotetext{
${ }^{2}$ Klaus Ferdinand Gärditz, Herrschaftslegitimation und implizite Identitätskontrolle, VerFBloG (May 21, 2020), https:// verfassungsblog.de/herrschaftslegitimation-und-implizite-identitaetskontrolle/.

${ }^{3}$ Frank Schorkopf, Antwort auf eine entgrenzte Politik, FAZ (May 8, 2020), https://www.faz.net/einspruch/ezb-urteil-desbundesverfassungsgerichts-entgrenzte-politik-16760094.html.

${ }^{4}$ Ana Bobić \& Mark Dawson, What Did the German Constitutional Court Get Right in Weiss II?, EULAWLIVE (May 12, 2020), https://eulawlive.com/op-ed-what-did-the-german-constitutional-court-get-right-in-weiss-ii-by-ana-bobic-and-markdawson/.

${ }^{5}$ Dieter Grimm, Jetzt war es so weit, FAZ (May 18, 2020), https://www.faz.net/aktuell/feuilleton/debatten/ezb-urteil-jetztwar-es-so-weit-16773982.html.

${ }^{6}$ Franz C. Mayer, Auf dem Weg zum Richterfaustrecht?, VerfBloG of May 7, 2020, https://verfassungsblog.de/auf-demweg-zum-richterfaustrecht/.

${ }^{7}$ Martin Nettesheim, Das PSPP-Urteil des BVerfG - ein Angriff auf die EU?, 2020 NeUE JuristisCHE WOCHENSCHRIFT [NJW] 2020, 1631, 1632.

${ }^{8}$ Ingolf Pernice, Machtspruch aus Karlsruhe: "Nicht verhältnismäßig? Nicht verbindlich? Nicht zu fassen...", EUROPÄISCHE ZEITSCHRIFT FÜR WIRTSCHAFTSRECHT [EUZW] 508 (2020); Jacques Ziller, The Unbearable Heaviness of the German Constitutional Judge, CERIDAP 87, 93 (May 7, 2020), https://ceridap.eu/the-unbearable-heaviness-of-the-german-constitutionaljudge-on-the-judgment-of-the-second-chamber-of-the-german-federal-constitutional-court-of-5-may-2020-concerningthe-european-central-banks-pspp/; Bernhard Wegener, Stellungnahme zur öffentl. Anhörung des BT-Europaausschusses, Doc 19(21)99, 4 et seq., https://www.bundestag.de/resource/blob/697490/19e094bd52ec5e0f4b22625644177275/wegener-data.pdf.

${ }^{9}$ Pernice, supra note 8.

${ }^{10}$ Daniel Sarmiento, Requiem for Judicial Dialogue, 16 EULAwLive 9 (2020).

${ }^{11}$ Heiko Sauer, Substantive EU Law Review Beyond the Veil of Democracy, 16 EULAwLive 1 (2020).

${ }^{12}$ Christian Calliess, Stellungnahme zur öffentl. Anhörung des BT-Europaausschusses, Doc 19(21)101, 8, https://www. bundestag.de/resource/blob/697584/69ec62de394a6348f992c1e092fa9f4b/callies-data.pdf.

${ }^{13}$ Corinna Budras, Bundesbank muss EZB Einhaltung der Vorgaben bescheinigen, FAZ (June 29, 2020), https://www.faz.net/ aktuell/wirtschaft/mehr-wirtschaft/verfassungsrichter-huber-kritisiert-mangelnde-kooperation-der-ezb-16836457.html; Wolfgang Janisch \& Stefan Kornelius, Eine "geradezu homöopathische" Botschaft an die EZB, SUEDDEUTSCHE ZEITUNG, 5 (May 12, 2020), https://www.sueddeutsche.de/politik/nach-urteil-zu-anleihekaeufen-eine-geradezu-homoeopathische-botschaftan-die-ezb-1.4905591; Reinhard Müller, "Das EZB-Urteil war zwingend”, FAZ, 2 (May 12, 2020), https://www.faz.net/ aktuell/politik/inland/peter-huber-im-gespraech-das-ezb-urteil-war-zwingend-16766682.html; Andreas Voßkuhle, "Erfolg ist eher kalt", ZEITONLINE (May 13, 2020).
} 
Federal Court of Justice. ${ }^{14}$ On the side of the EU, the CJEU reacted by publishing a press release, ${ }^{15}$ an unprecedented step with regard to a national decision. While the European Commission is still considering initiating an infringement procedure against Germany, the Governing Council of the ESCB has, in the meantime, made available key elements of its proportionality assessment-which it had already conducted previously — to the public. ${ }^{16}$ It also empowered the German Federal Bank to transmit several formerly confidential documents to the Federal Government and the Bundestag. ${ }^{17}$ On that basis, both the Bundestag and the Federal Ministry of Finance have expressed the view that the ECB had demonstrated in a comprehensible and substantiated manner that PSPP corresponds to the requirement of proportionality. ${ }^{18}$

Although the direct consequences of the decision are therefore limited, the decision reveals a number of paradoxes that exceed the mere case at hand. In this contribution we will focus, in a first step, on the legal paradoxes, relating inter alia to the standard of review, the principle or proportionality, the intensity of judicial review, and the FCC's view that better reasoning could ultimately turn an ultra vires act into a lawful act. For reasons of space, we will only deal with the FCC's most important arguments on the (alleged) ultra vires acts of the ECJ and the ECB and will not deal with the problem of Article 123 TFEU (B.). In a second step, we will address the paradoxes relating to the decision's context, in particular to the rule of law crisis, the reform of the EMU and the principle of democracy (C.), before treating, in a third and final step, the paradox relating to the legal community (D.).

\section{B. The Legal Paradoxes}

Whatever other dimensions the decision may have-political, economic, historical, personal—the legal are of particular importance, given that the law is the primary language of a court. It is the language it should master, especially when accusing others of an outright failure to do so. And it is for this very reason a language that we should take seriously. Some observers held that the arguments against the legality of PSPP had been "rightly rejected as rubbish" by the CJEU. ${ }^{19}$ Others argued that the FCC was in principle right to dismiss the purely symbolic nature of the CJEU's judicial review and to oppose the executivist bias of EU law, a bias reminiscent of Schmitt and Forsthoff and defended by EU legal scholars who were characterized by an uncritical submissiveness to authority. ${ }^{20}$ Still others expressed the view that any student "who was a good positivist" would "not be surprised" by the FCC's judgment "in the least" and that the critical academic reaction would tell us something about the "changing nature of EU law as a discipline," because we would now expect courts "to be political actors." ${ }^{\prime 1}$ What such statements certainly tell us-apart from the fact that we now have the ultimate test of who is a good positivist and who is not-is that a little more modesty from all sides could be helpful. With regard to the PSPP, we should acknowledge that there are different opinions on this rather complicated issue, opinions which are neither "rubbish" nor based on an "instinctive reflex,"22 nor should be discredited as Schmittian (the

\footnotetext{
${ }^{14}$ Peter Meier-Beck, Ultra vires?, D’KART (May 11, 2020), https://www.d-kart.de/en/blog/2020/05/11/ultra-vires/.

${ }^{15}$ Court of Justice of the European Union Press Release 58/20, Press release following the judgment of the German Constitutional Court of 5 May 2020 (May 8, 2020).

${ }^{16}$ European Central Bank, Account of the Monetary Policy Meeting of the Governing Council of the European Central Bank, Eurosystem (June 3 \& 4, 2020), https://www.ecb.europa.eu/press/accounts/2020/html/ecb.mg200625 fd97330d5f.en.html.

${ }^{17}$ Decision of June 24, 2020 as referred to by Bundestag Decision of July 2, 2020, Urteil des Bundesverfassungsgerichts zum Anleihekaufprogramm PSPP der Europäischen Zentralbank, Doc No 19/20621.

${ }^{18}$ See Bundestag Decision of July 2, 2020, supra note 17.

${ }^{19}$ Federico Fabbrini, Eurozone auf Wiedersehen, BRIDGE NeTwORK BLOG (May 5, 2020), https://bridgenetwork.eu/2020/05/ 05/1369/?fbclid=IwAR32ISceQjltUJYtZ24Vu6GxApKvUIQis7KEC-v4lm7fiTlY-1hVtmDz-cs.

${ }^{20}$ Gärditz, supra note 2.

${ }^{21}$ Bobić \& Dawson, supra note 4 .

${ }^{22} I d$.
} 
ultimate killer argument, now turned against EU law), but positions that can be more or less convincingly defended on the basis of EU or national law.

\section{A Problem of Constitutional Pluralism?}

According to our reading, the legal paradox is not automatically inherent in the fact that the FCC declares a judgment of the CJEU and a programme of the ECB ultra vires. Certainly, from the perspective of EU law such a finding constitutes an open breach of law, because it disrespects the CJEU's monopoly of interpretation and the binding force of preliminary rulings and thereby endangers the equal and effective application of EU law across the Union. However, from the perspective of national constitutional law, it lies in the very logic of ultra vires review that a constitutional court may ultimately, albeit exceptionally, declare an act of EU law non-binding at the domestic level. ${ }^{23}$ It also lies in the very logic of constitutional pluralism. ${ }^{24}$ The positions of the CJEU and the FCC, which are both logical in themselves, are incommensurable with regard to the very foundations of EU law. This can ultimately lead to different results.

Against this background it is important to note that criticizing the FCC's reasoning must not necessarily go along with calls for renouncing the theory of constitutional pluralism or certain versions of it. Neither is this theory to be abandoned simply because it can be misused for the wrong purposes by autocratic regimes, ${ }^{25}$ nor should it be rejected because it "can't provide a practical, ultimate answer to the question at the heart of the Kompetenz-Kompetenz conundrum." 26 We should be careful with "ultimate" answers, claims to the "last say," and conceptual re-entries of undivided sovereignty, also from the perspective of EU law. Above all, we should be generally sceptical as to the idea of "ultimate" solutions from an academic, epistemological point of view.

The actual legal paradoxes of the PSPP decision do not, according to our reading, primarily relate to the fact that, but the way how, i.e. on the basis of which premises and arguments, the FCC draws the conclusion that both the CJEU and the ECB have manifestly exceeded their competences. It is the sad irony of the PSPP judgment that the FCC, while accusing the CJEU and the ECB of manifestly exceeding their competences, does not sufficiently adhere to its own standards and increasingly risks overstretching the boundaries of its mandate under the Basic Law. Herein lies the threat to the supranational community of law, a fact to which we will return.

\section{Sentenced to Debate: The Paradox of Unconstitutional Inactivity}

Formally, the FCC subjected acts of EU law only indirectly to ultra vires review. ${ }^{27}$ In PSPP, similarly to OMT, ${ }^{28}$ the constitutional complaints-introduced by more or less the same group of

\footnotetext{
${ }^{23}$ For the conceptual challenges of ultra vires review, see in detail FRANZ C. MAYER, KOMPETENZÜBERSCHREITUNG UND LeTZTENTSCHEIDUNG 11 et seq. (2000). For a comparative overview, see 1 Franz Mayer \& Mattias Wendel, ENZYKLOPÄDIE EUROPARECHT, $\$ 4$ (2d ed., forthcoming 2020).

${ }^{24}$ For the concept in the context of EU law, see CONSTitutional Pluralism In The European UNiON AND BEyOND (Matej Avbelj \& Jan Komárek eds., 2012).

${ }^{25}$ Cf. Philipp Fritz, "Karlsruhe ist nicht Polen", Die Welt 6 (May 14, 2020), https://www.welt.de/politik/ausland/ plus207975833/Verfassungsrechtler-Karlsruhe-ist-nicht-Polen.html (interviewing Jan Komárek).

${ }^{26}$ R. Daniel Keleman et al., National Courts Cannot Override CJEU Judgments, VerfBlog (May 26, 2020), https:// verfassungsblog.de/national-courts-cannot-override-cjeu-judgments/ (painting a rather undertheorized and utilitarian picture of constitutional pluralism when stating that it had been developed by scholars "as a way to resolve the impasse between the CJEU and national constitutional courts."). A theoretically more profound critique of constitutional pluralism argues that constitutional disagreements cannot be excluded as such, but should rather be dealt with in the framework of democratic procedures than by constitutional courts, see Nik de Boer, The False Promise of Constitutional Pluralism, AMSTERDAM LAW SCHOOL ReSEARCH PAPER 2018-05, https://ssrn.com/abstract=3141760.

${ }^{27}$ See PSPP, at para. 89 (explaining further and providing additional references).

${ }^{28}$ Bundesverfassungsgericht [BVerfG] [Federal Constitutional Court] Jan. 14, 2014, 134 ENTSCHEIDUNGEN DES BUNDESVERFASSUNGSGERICHTS [BVERFGE] 366 [hereinafter OMT-reference].
} 
conservative and right-wing politicians and economists-were directed against an unconstitutional inactivity of German state organs. The FCC considered admissible and (partly) wellfounded the constitutional complaints directed against the Federal Government and the Bundestag. It held that both institutions had violated the complainants' "right to democratic self-determination" 29 by failing to take "suitable steps" challenging that the ECB had "neither assessed nor substantiated" that PSPP satisfied the principle of proportionality. ${ }^{30}$

The fact that the FCC accuses parliament and government of having violated the inalienable core of the principle of democracy-to which the right to democratic self-determination is intrinsically linked ${ }^{31}$ —is an exorbitant and immoderate allegation. ${ }^{32}$ Under Article 130 TFEU and arguably also under Article 88 of the Basic Law neither parliament nor government is entitled to influence the ECB at any point. But even if we argue that these provisions on the ECB's independence from politics do not apply to the extent that the ECB allegedly acts outside its mandate (an approach open to abuse), we encounter a paradox: The FCC is not able to sufficiently specify, in terms of constitutional law, what parliament and government should actually do in order to stop the alleged violation of competences on part of the EU. Can there be a justiciable individual right to demand non-specifiable, even pointless measures by state organs? In this context it is worth re-reading the two dissenting opinions on the FCC's preliminary reference in OMT which already argued in detail why the approach of the FCC to declare admissible constitutional complaints such as those in question does not find a sufficient basis in German constitutional law. ${ }^{33}$

To frame it differently, one of the paradoxes of OMT and PSPP lies in the fact that the FCC, relying on the essence of the principle of democracy, exercises ultra vires review on the basis of an arguably self-proclaimed competence to adjudicate on an alleged unconstitutional inactivity of parliament and government, without being able to even legally specify what these institutions should actually do in order to stop the alleged ultra vires act on which they have no direct influence. ${ }^{34}$ The only instruction given by the FCC in its PSPP judgment is that both government and parliament should "take steps seeking to ensure that the ECB conducts a proportionality assessment in relation to the PSPP" and that they had to "clearly communicate their [sic] legal view to the ECB or take other steps to ensure that conformity with the Treaties is restored." 35 This is as concrete as it gets. In the end, the Bundestag and the Federal Government expressed, as we have seen, their legal view, according to which the ECB had sufficiently demonstrated that PSPP was proportional.

\section{Ultra Vires, Take One: The CJEU's Weiß Judgment}

The FCC's reasoning appears to be particularly paradoxical as regards the evaluation of the CJEU's Weiß judgment.

\footnotetext{
${ }^{29}$ PSPP, at paras. 100 and 101 (“Anspruch auf demokratische Selbstbestimmung”). In Bundesverfassungsgericht [BVerfG] [Federal Constitutional Court] June 21, 2016, 142 ENTSCHEIDUNGEN DES BundesverfassungsGeriCHTS [BVERFGE] 123 [hereinafter OMT-judgment], paras 133, 147, 166, 185 the FCC had repeatedly spoken of a "right to democracy" ("Recht auf Demokratie" or "Anspruch auf Demokratie"), a term which the FCC itself had put in quotes. In PSPP this term is used only with regard to the principle of conferral (para. 158) and in the context to the responsibility with regard to European integration (para. 230).

${ }^{30} P S P P$, at para. 116.

${ }^{31}$ According to the FCC's approach the right to democratic self-determination is based on Article 38(1) first sentence in conjunction with Article 20(1) and (2) and Article 79(3) of the German Basic Law, Grundgesetz [GG], translation at http:// www.gesetze-im-internet.de/englisch_gg/index.html.

${ }^{32}$ For similar conclusions see Nettesheim, supra note 7, at 1632.

${ }^{33} \mathrm{See}$ Bundesverfassungsgericht [BVerfG] [Federal Constitutional Court] Jan. 14, 2014, 134 ENTSCHEIDUNGEN DES BundeSVERFASSUNGSGERICHTS [BVERFGE] 366 (dissenting opinions of Judges Lübbe-Wolff and Gerhardt).

${ }^{34}$ For more details, see Franz C. Mayer, Rebels Without a Cause?, 15 German L.J. 111 (2014); Mattias Wendel, Exceeding Judicial Competence in the Name of Democracy, 10 EUR. CONST. L. REv. 263 (2014).

${ }^{35} \mathrm{PSPP}$, at para. 232.
} 


\section{The Standard of Review Paradox}

The relevant standard of review is a hybrid one. Ultra vires review is rooted in national constitutional law, but inevitably stretches out into EU law. In the case of Germany, the FCC aims to ensure by means of an ultra vires review that the exercise of public authority at EU level does not exceed the "programme of integration" which has been consented to, in Germany, by a parliamentary statute on the basis of Article 23(1) and within the limits of the so-called eternity clause under Article 79(3) of the Basic Law. However, the precise content and scope of the conferral of competences to the EU can only be determined with regard to the Treaties. Despite being framed in terms of national law and having binding force only on national bodies, every ultra vires decision therefore necessarily implies an interpretation of EU law. If the FCC rules that the EU has allegedly acted ultra vires, it claims, in substance, also a violation of EU law.

Within the legal framework of European multilevel constitutionalism, ${ }^{36}$ the only tolerable ${ }^{37}$ approach towards judicial reservations such as identity or ultra vires review is to construe them as safeguard mechanisms for exceptional cases, as constitutional counter-balances of last resort. In his academic writings, the former president of the FCC, Andreas Voßkuhle, described these reservations as unilateral "emergency breaks" that are justified in a non-hierarchical setting precisely by the fact that they do not ultimately have to be applied..$^{38}$ The FCC's Second Senate has repeatedly stressed that such reservations had to be construed narrowly in the light of the Basic Law's openness towards EU law. ${ }^{39}$ As regards ultra vires review in particular, the FCC limited it to manifest and structurally significant transgressions of competences by EU institutions, bodies or agencies. ${ }^{40}$

Specifically with regard to the Court of Justice, the FCC repeatedly underlined that it was not the FCC's task "to substitute the CJEU's interpretation with its own when faced with questions of interpreting EU law." ${ }^{31}$ Even in its PSPP decision, the FCC openly acknowledged that the "interpretation and application of EU law, including the determination of the applicable methodological standards, primarily falls to the CJEU" which has to be granted also a "certain margin of error." ${ }^{2}$ According to its own standards, the FCC has to respect judgments by the CJEU even if the latter "adopts a view against which weighty arguments could be made" as long as the CJEU's decision was not "objectively arbitrary" and still based on "recognised methodological principles." 43

Against this background one would expect the FCC to deliver a sound reasoning providing adequate justifications why the FCC's assumption of a breach of competences is clearly preferable to the counterarguments. ${ }^{44}$ However, the arguments and legal premises on which the FCC relies in order to demonstrate a manifest transgression of competences by the CJEU and the ECB are questionable to such a remarkable extent that they fail to meet these specific requirements. Not only with regard to EU law, but interestingly also with regard to German constitutional law, the FCC's reasoning hardly complies with the standards of legal persuasiveness that the FCC sets itself for ultra vires review.

\footnotetext{
${ }^{36}$ Pernice, supra note 8.

${ }^{37}$ Both from the perspectives of EU and national law.

${ }^{38}$ Andreas Voßkuhle, Der europäische Verfassungsgerichtsverbund, 29 NEUE ZEITSCHRIFT FÜr VERWALTUNGSRECHT [NVwZ] 1, 3, 7 (2010).

${ }^{39}$ Starting with Bundesverfassungsgericht [BVerfG] [Federal Constitutional Court] June 30, 2009, 123 ENTSCHEIDUNGEN DES BundeSVERFASSUNGSGERICHTS [BVERFGE] 267, paras. 240-241 [hereinafter Lisbon Judgment].

${ }^{40}$ See Bundesverfassungsgericht [BVerfG] [Federal Constitutional Court] July 6, 2010, 126 ENTSCHEIDUNGEN DES BuNDESVERFASSUNGSGERICHTS [BVERFGE] 286, para. 61 [hereinafter Honeywell]; PSPP, at para. 100.

${ }^{41}$ Honeywell, at para. 66; PSPP, at para. 112 .

${ }^{42} P S P P$, at para. 112. For the margin of error, see Honeywell, at para. 66.

${ }^{43} P S P P$, at para. 112 .

${ }^{44} \mathrm{Cf}$. the case law on GG art. 101(1), according to which ordinary or specialized court of last instance violate the right to a lawful judge arbitrarily "when possible counterarguments are clearly preferable to the opinion held by the [non-referring] court on the relevant question" of EU law, Bundesverfassungsgericht [BVerfG] [Federal Constitutional Court] May 31, 1990, 82 ENTSCHEIDUNGen DEs Bundesverfassungsgerichts [BVerfGE] 159, para. 137; Honeywell, at para. 90.
} 


\section{The Proportionality Paradox}

The FCC's criticism of Weiß aims particularly at the CJEU's proportionality test. At the same time, the FCC's own conception of proportionality is particularly questionable. ${ }^{45}$

\section{a) The Great Competence Balance}

According to the FCC, the CJEU's method to apply the principle of proportionality renders "that principle meaningless for the purposes of distinguishing" 46 between the competences of the EU and those of its Member States. If the CJEU were to be followed, the principle of proportionality would lose its corrective function for safeguarding the competences of the Member States, a fact which would also render "meaningless the principle of conferral." 47 In the FCC's view, the question of whether the ECB has acted within its mandate under the Treaties should ultimately be answered by a process of balancing. ${ }^{48}$ The FCC's conception can thus be captured by the image of a competence balance: If it tilts towards monetary policy, the ECB is competent to enact the bond purchase programme, if it tilts towards economic policy, the ECB lacks competence.

\section{b) Proportionality as a Means for Delimitating Competences?}

From the perspective of EU law, this is an astonishing approach. ${ }^{49}$ Indeed, if one expects the principle of proportionality under Articles 5(1) and (4) TEU to serve the purpose of delimitating ${ }^{50}$ competences, one cannot but be disappointed by Weiß. Here as well as in Gauweiler, ${ }^{51}$ the CJEU applied a two-step test. ${ }^{52}$ In a first step, it addressed the delimitation of competences, determining whether or not the PSPP fell within the exclusive competences conferred upon the ESCB in the field of monetary policy. ${ }^{53}$ In a second step, the CJEU applied the principle of proportionality to the concrete exercise of the ECB's exclusive competence at a length of 30 out of the decision's total of 168 paragraphs. ${ }^{54}$

The approach taken by the CJEU corresponds to the relevant Treaty provisions which establish a major conceptual distinction. ${ }^{55}$ According to Article 5(1) TEU, the principle of conferral governs the limits of EU competences while the principle of proportionality governs the use of EU competences. Hence, the principle of proportionality presupposes an existing EU competence ${ }^{56}$ and limits, similarly to the principle of subsidiarity, ${ }^{57}$ its exercise by the EU. In German textbooks this function of limiting or guiding the use of an existing EU competence in casu is captured by the term Kompetenzausübungsschranke ${ }^{58}$ or Kompetenzausübungsregel. ${ }^{59}$ Until its PSPP decision, the FCC relied on similar expressions, speaking inter alia of Zuständigkeitsausübungsregeln. ${ }^{60} \mathrm{We}$ are

\footnotetext{
${ }^{45}$ See in particular the authors mentioned in supra note 8.

${ }^{46} P S P P$, at paras. $119,127,139$ (emphasis added).

${ }^{47} I d$. at paras. 123,133 et seq. and 160.

${ }^{48} I d$. at paras. 139 et seq.

${ }^{49}$ For a similar conclusion see Pernice, supra note 8; Ziller, supra note 8.

${ }^{50}$ In the original German version, the FCC speaks of "Abgrenzung" ( $c f$. paras. 127 and 139), a term which corresponds to the German version of Treaty on European Union, art. 5(1) and is better translated with "delimitation" instead of "distinguishing" as used in the FCC's English translation.

${ }^{51}$ ECJ, Case C-62/14, Peter Gauweiler and Others v. Deutscher Bundestag, ECLI:EU:C:2015:400 (June 16, 2015), paras. 46, 66, http://curia.europa.eu/juris/liste.jsf?num=C-62/14 [hereinafter Gauweiler].

${ }^{52}$ ECJ, Case C-493/17, Heinrich Weiss and Others, ECLI:EU:C:2018:1000 (Dec. 11, 2018), paras. 46-52, http://curia.europa. eu/juris/liste.jsf?num $=\mathrm{C}-493 / 17$ [hereinafter Weiß].

${ }^{53} \mathrm{Id}$. at paras. $53-70$.

${ }^{54}$ Id. at paras. $71-100$

${ }^{55}$ See also Pernice, supra note 8.

${ }^{56}$ See Paul Craig \& Grainne de Burca, EU Law: Text, Cases, and Materials 96 ( $6^{\text {th }}$ ed., 2015) (according to whom the Treaty "distinguishes between the existence and the use of competence.").

${ }^{57}$ Which does not apply to the exercise of exclusive competences such as monetary policy, see Treaty on the European Union art. 5(3)

${ }^{58}$ Literally "limit to the use of competences." See Rudolf Streinz, Europarecht 177 (11th ed., 2019).

${ }^{59}$ Literally "rule on the use of competences". See DANIEL DitTERT, Europarecht 93 (5th ed., 2017).
} 
referring specifically to these German expressions in the present context, because they illustrate that the conceptual distinction made by the Treaties is also well reflected in German doctrine, a fact of which the FCC must have been aware of. All of these terms reflect the idea that the principle of proportionality as enshrined in Articles 5(1) and (4) TEU does not relate to the delimitation, but to the exercise of EU competences.

This distinction drawn in Article 5(1) TEU is much more than a doctrinal subtlety. It implies that the question of whether or not the EU has competence depends on whether there is a legal base in the Treaties which applies to the case at hand. ${ }^{61}$ In case of PSPP, the relevant legal base ${ }^{62}$ is framed in terms of objectives and instruments, a fact also highlighted by the CJEU. ${ }^{63}$ In contrast, the question of competence does not depend on the adherence to proportionality. If the principle of proportionality did "also appl[y] to the division of competences," as suggested by the FCC, ${ }^{64}$ this would lead to the strange consequence that Member States had to be qualified as competent as far as the EU acted disproportionately. The question of competence would be in constant motion in both directions. In fields of exclusive competences, to which we limit our considerations in the present context, such an approach would not only run counter to the conceptual distinction made in Article 5(1) TEU between the principle of conferral (governing the delimitation of competences) and the principle of proportionality (governing the use of competences). It would also stand in contrast to the pre-emptive effect of exclusive competences under Article 2(1) TFEU. Contrary to the insinuation of the FCC that the CJEU would apply the principle of proportionality, because "a generous interpretation of the specific competence conferred may, to a certain extent, be compensated by a sound proportionality assessment," 65 the CJEU applies the proportionality test, because it follows the structure of Article 5(1) TEU which demands to address the delimitation of competences firstly and the limits to the use of competence secondly.

\section{c) Lack of Competence and Unlawfulness}

If an act of EU law violates Article 5(4) TEU, the EU has not acted beyond its competences-ultra vires - but has acted unlawfully within the realm of its competences. ${ }^{66}$ This is the case, for instance, if the EU legislator enacts a regulation where a directive would have sufficed, as also reflected in Article 296(1) TFEU. Against this background, mixing up the principle of conferral with the principle of proportionality implies mixing up the concept of lack of competence with the concept of unlawfulness. Within the framework of ultra vires review this means, in essence, developing ultra vires review further into a general review of legality which it is not supposed to be even under the FCC's own standards. ${ }^{67}$ With its PSPP decision the FCC performs precisely such a review of legality, acting "as if it were the Supreme Court of the EU." 68 In future cases, it would require only a small step for the FCC to declare itself competent, on the basis of the PSPP decision, to generally review the proportionality of EU acts in order to allegedly safeguard the right to democratic self-determination of German voters-a danger also highlighted by initial comments. ${ }^{69}$

\footnotetext{
${ }^{60}$ Lisbon Judgment, at para. 304 (“Zuständigkeitsausübungsregeln”); OMT (final judgment), at para. 179 ("begrenzendes Korrektiv" and "Ebene der Kompetenzausübung").

${ }^{61}$ In the case of PSPP, the legal base was (as in OMT) Statute of the European System of Central Banks and of the European Central Bank art. 18.1 (1998) [hereinafter ESCB Statute].

${ }^{62}$ ESCB Statute art. 18.1; Treaty on the Functioning of the European Union arts. 127, 282(2), May 9, 2008, 2008 O.J. (C 115) 47 [hereinafter TFEU].

${ }^{63}$ Wei $\beta$, Case C-493/17 at para. 53 et seq.; Gauweiler, Case C-62/14 at para. 46 et seq.

${ }^{64}$ PSPP, at para. 119.

${ }^{65} \mathrm{Id}$. at para. 128.

${ }^{66}$ For the conceptual difference between lack of competence and illegality, see already Martin Nettesheim, Kompetenzen, in Europäisches VerfassungsReCHT 389, 408-409 (Jürgen Bast \& Armin von Bogdandy eds., 2009).

${ }^{67}$ For a similar conclusion see Nettesheim, supra note 7 , at 1632.

${ }^{68}$ Aptly Sauer, supra note 11 , at 8.

${ }^{69}$ See Thomas Ackermann, Das europäische Wettbewerbsrecht als Kollateralschaden des PSPP-Urteils des Bundesverfassungsgerichts?, 8 NEUE ZEITSCHRIFT FÜr KARTELLRECHT [NZKART] 281 (2020).
} 


\section{d) Intersection of Monetary and Economic Policy}

But even if we accept that adherence to proportionality should be subject to ultra vires review by the FCC - just like adherence to Article 123 TFEU does since OMT - the FCC's reasoning is, in substance, not preferable to that of the CJEU. Not only does the CJEU's approach correspond to the normative framework of Articles 5(1) and (4) TEU whereas the FCC's does not, as demonstrated above. The CJEU also convincingly takes account of the conceptual intersection of monetary and economic policy, acknowledging that measures of monetary policy necessarily entail effects on the real economy, effects without which the ECB could not influence inflation rates and achieve its primary goal of price stability. ${ }^{70}$ The CJEU therefore convincingly rejects the argument of the FCC according to which open market operations could not be qualified as acts of monetary policy as far as the ECB could foresee or did even knowingly accept significant effects on the real economy-effects that could also be pursued by means of economic policy, albeit for different purposes. ${ }^{71}$ If the ESCB was generally prevented from taking measures the economic effects of which are foreseeable or knowingly accepted, the ECB might no longer be able to fulfil its primary task of maintaining price stability. ${ }^{72}$

\section{e) Teaching Lessons in Proportionality}

The FCC's conception of proportionality under Article 5(4) TEU is also a new approach. By relying on the principle of proportionality for the purpose of delimitating competences, the FCC has not only deviated from the normative framework of the Treaties, as demonstrated above, but also from its own case law. Admittedly, already back in its OMT-reference of 2014, the FCC framed the relevant competence test in terms of whether or not the ECB programme constitutes "predominantly an act of economic policy," ${ }^{73}$ a test which does not fully correspond to the test under the relevant legal base of EU law. ${ }^{74}$

However, in its OMT-reference of 2014, the FCC did not rely on the principle of proportionality. In fact, the OMT-reference did not even mention that principle. The first to apply the proportionality test to the OMT programme was Advocate General Cruz Villalón, ${ }^{75}$ followed by the CJEU in Gauweiler. ${ }^{76}$ Both the Advocate General and the Court of Justice referred to proportionality as a principle limiting the (potential) ${ }^{77}$ exercise of the ECB's competences. Hence, it could have been perceived as an historic irony that the German FCC was taught a lesson in proportionality by a European court. In its final OMT judgment, the FCC eventually held that there was no manifest transgression of competences on behalf of the ECB, because the CJEU had, by relying on the principle of proportionality, limited the OMT programme in an acceptable manner "with regard to the exercise of competences." ${ }^{78}$ Even in its PSPP reference, in which the FCC had spent one single (!) paragraph on proportionality, ${ }^{79}$ alongside three on the necessity to take into consideration the "economic policy effects" 80 and another one on motivation, ${ }^{81}$ it did not explicitly connect proportionality with the delimitation of competences. It was only in its final decision that

\footnotetext{
${ }^{70}$ Weiß, Case C-493/17 at paras. 64-67.

${ }^{71} I d$. with regard to Bundesverfassungsgericht [BVerfG] [Federal Constitutional Court] July 18, 2017, 146 ENTSCHEIDUNGEN DES BUNDESVERFASSUNGSGERICHTS [BVERFGE] 216 [hereinafter PSPP-reference], paras. 119-121.

${ }^{72}$ Wei $\beta$, Case C-493/17 at para. 67.

${ }^{73}$ OMT-reference, at para. 69.

${ }^{74}$ See Jürgen Bast, Don't Act Beyond Your Powers, 15 German L.J. 167, 175 (2014); Wendel, supra note 34, at 292 et seq.

${ }^{75}$ Opinion of Advocate General Cruz Villalón at para. 159, Case C-62/14, Peter Gauweiler and Others v. Deutscher Bundestag (Jan. 15, 2014).

${ }^{76}$ Gauweiler, Case C-62/14 at paras. $66-92$.

${ }^{77}$ The OMT programme was only announced and never put to practice.

${ }^{78}$ OMT-judgment, at para. 190 (emphasis added).

${ }^{79}$ PSPP-reference, at para. 122.

${ }^{80} I d$. at paras. $119-121$.

${ }^{81} I d$. at para. 123 .
} 
the FCC considered it necessary to construe the principle of proportionality as a principle of delimitating competences and to teach the CJEU a lesson in return of how to handle it.

\section{f) German Idiosyncrasies?}

Can the FCC's call for the European Court of Justice to rely on the principle of proportionality in order to delimitate competences perhaps be traced back to peculiarities of German constitutional law? After all, it is one of the conceptual challenges of ultra vires review that national constitutional courts take a look at EU law through the looking glass of national constitutional law, thereby risking the production of an idiosyncratic and arguably distorted image of EU law. However, under German constitutional law,

"[1]imits derived from the principle of the rule of law to the interference of public authority in the legal sphere of individuals cannot be applied to the relationship between the federation and the federal states in terms of competence. This is particularly the case with the principle of proportionality $[\ldots]$. The underlying rationale of freedom and interference cannot be transferred [...] to the delimitation of competences in general." 82

This section is not taken from a long forgotten paper representing some kind of minority opinion, but from one of the FCC's leading cases on the relationship between the Bund and the Länder, the so-called Kalkar II decision. In other words, the fact that the FCC insists on proportionality as an instrument for delimitating competences not only cannot be explained by the peculiarities of German constitutional law, but even directly contradicts them. ${ }^{83}$

To be sure, it could be an academically interesting question of whether or not the principle of proportionality could or should serve as a tool for delimitating competences and whether disproportionality could or should be equated to a lack of competence. Why not write a book about it? However, it is certainly not a sufficiently solid basis for accusing another court, which follows the classical approach, of methodological arbitrariness.

\section{The Judicial Review Paradox}

Another line of reasoning, closely intertwined with the aspect of proportionality, relates to the intensity of judicial control, Kontrolldichte in German. It appears that the main concern of the FCC is that the CJEU's approach towards judicial review would make the ECB a legally largely uncontrolled institution, an institution that could take decisions of enormous economic and social impact without having sufficient democratic legitimation and that could even decide, to some extent, on the scope of its own mandate. According to the FCC, the "self-imposed restraint" of the CJEU to limit judicial review to manifest errors ${ }^{84}$ had the effect of widely exempting the ECB from judicial review and was "by no means conducive to restricting the scope of the competences conferred upon the ECB," rather allowing it to gradually expand its competences on its own authority. ${ }^{85}$ More specifically, the FCC criticizes the CJEU in three ways: Firstly, for not taking into consideration sufficiently the factual consequences of PSPP in terms of economic policy and for accepting the proclaimed objectives of the ECB more or less as if they were a

\footnotetext{
${ }^{82}$ Bundesverfassungsgericht [BVerfG] [Federal Constitutional Court] Case No. 2BvG 1/88, para. 105, (May 22, 1990) (author's translation).

${ }^{83} \mathrm{Cf}$. Wegener, supra note 8 , at 5 . One could of course argue that the FCC's case law on national federalism is not transferable to the EU, which is not itself a state. But then the FCC does not provide sufficient justification as to why the principle of proportionality should be of crucial importance for the delimitation of competences between the EU and its Member States, whereas it should not generate any added value for the delimitation of areas of competence between the Bund and the Länder, which seems to be a functionally equivalent problem.

${ }^{84}$ See Weiß, Case C-493/17 at para. 56 (regarding the delimitation of competences), paras. 73, 81, 86, 91 (regarding proportionality).

${ }^{85}$ PSPP, at para. 156.
} 
fact; ${ }^{86}$ secondly, for carrying out a proportionality test without a proper balancing of conflicting interests ${ }^{87}$ thirdly, for not complying with the CJEU's own standards of proportionality in other fields of EU law. ${ }^{88}$ In short, the CJEU's approach would deprive judicial control of its effectiveness and render the CJEU's decision arbitrary.

This part of the FCC's reasoning certainly reflects profound and legitimate concerns about how to maintain structures of accountable decision-making in the face of the skyrocketing dimensions of the bond purchase programme(s) and the uncertainty of their future implications. It is perhaps also the concern to which the CJEU responded with the comparatively lowest degree of sensitivity and argumentative substance. With regard to the delimitation of competences, the CJEU (convincingly) underlined that the functioning of monetary policy necessarily depends on certain effects on the real economy. ${ }^{89}$ However, the CJEU arguably failed to offer an alternative test that could help to screen out measures which could no longer be based on Article 18.1 of the ESCB statute, because they did not sufficiently serve the monetary objective indicated by the ECB.$^{90}$ Such a test might have, perhaps, enhanced the effectiveness of judicial review to a certain degree. And with regard to proportionality, the CJEU included in its examination only some of the arguments or potential effects of the programme listed by the FCC. ${ }^{91}$ Indeed, the CJEU's review could have been more thorough.

However, the question remains whether this renders the CJEU's reasoning already arbitrary and therefore constitutes a manifest transgression of the Court of Justice's mandate under Article 19(1) sentence 2 TEU. There are good reasons why this is not the case. Judicial review of independent bodies enjoying discretion in a multi-levelled setting is a complicated question in general ${ }^{92}$ and in the Economic and Monetary Union (EMU) in particular. ${ }^{93}$ In this context, the FCC's call to the CJEU to conduct a more thorough judicial review must be seen against the background of German constitutional law which is based on the idea of a comparatively intense judicial scrutiny of public authority. This approach is based on Article 19(4) of the Basic Law, as reflected both in the PSPP judgment ${ }^{94}$ and in subsequent affirmative comments. ${ }^{95}$ However, this approach is neither identical to Article 47 of the Charter nor to Article 6 ECHR. ${ }^{96}$ It is also rather specific in a comparative perspective, given that the legal systems of several other Member States are more cautious (inter alia for reasons of democracy) as regards judicial control of public authority and attach greater importance and weight to techniques of judicial restraint. ${ }^{97}$ These legal traditions cannot be ignored by the CJEU when developing a genuine European standard. ${ }^{98}$ Hence, it should not come as a surprise that the CJEU's approach differs significantly from the German when it comes to the attribution of (administrative) discretion and judicial review. ${ }^{99}$

As regards judicial scrutiny of the ECB in particular, the CJEU relies essentially on a functional argument, highlighting that the ECB, makes "choices of a technical nature" and undertakes "complex forecasts and assessments" and therefore must be allowed a "broad discretion." 100 While such

\footnotetext{
${ }^{86} I d$. at paras. $134-137$.

${ }^{87} I d$. at paras. $138-145$.

${ }^{88} I d$. at paras. $146-153$.

${ }^{89}$ Wei $\beta$, Case $\mathrm{C}-493 / 17$ at para 66.

${ }^{90}$ For a critique of Wei $\beta$ in this respect, see Marijn van der Sluis, "Similar, Therefore Different", 46 LEG. IssUES ECON. INTEGRATION 263, 273 (2019).

${ }^{91}$ This is particularly true as regards the balancing, Weiß, Case C-493/17 at para. 93 et seq.

${ }^{92}$ Mattias Wendel, Verwaltungsermessen als Mehrebenenproblem 373 (2019).

${ }^{93}$ Matthias Goldmann, Adjudicating Economics?, 15 GERMAN L.J. 265, 266 (2014).

${ }^{94}$ PSPP, at para. 144.

${ }^{95}$ See Gärditz, supra note 2.

${ }^{96}$ See Wendel, supra note 92 , at $384,400$.

${ }^{97} \mathrm{Id}$. at 41 et seq.

${ }^{98}$ See Sarmiento, supra note 10 , at 17.

${ }^{99}$ For this difference, see ThOMAS VON DANWITZ, EUROPÄISCHES VERWALTUNGSRECHT 476 (2008).

${ }^{100} P S P P$, at para. 73 (regarding proportionality).
} 
a functional argument certainly cannot be the sole answer to the problem of judicial review, it should be noted that judicial review can only be as effective as the law is determinative. The less this is the case, the more lawyers should be advised to exercise restraint. Arguably, the law governing the EMU is in many ways not as determinative as EU law in other areas, say in the area of internal market. And arguably the Treaty Makers have put the ECB deliberately in place in order to decide on economically complex, controversial and prognostic questions on the basis of a rather abstract and finality-oriented legal framework. Against this background, there are substantive reasons for the CJEU to exercise judicial restraint, particularly as regards the question whether or not the measures taken by the ECB are suitable for attaining the ECB's objectives. One might as well oppose the CJEU's approach-equally on the basis of reasonable arguments and in particular stressing the need for thorough judicial review in the absence of democratic control. ${ }^{101}$ However, one can hardly call the Court of Justice's approach arbitrary. It may be a poor performance, an unlawful performance at most, but certainly not an ultra vires act. ${ }^{102}$

Interestingly, in the long history of the Bundesbank there has never been a case in which the FCC would have exercised comparable judicial control over the Bundesbank's decisions-despite the fact that the Bundesbank took, as does the ECB today, countermajoritarian decisions with significant economic and social impact. And with regard to the judicial review of the ECB, the FCC itself appears to follow primarily a procedural and therefore limited approach to judicial review, although not as limited as that of the CJEU. ${ }^{103}$ As far as the mode of judicial control is concerned, the differences between the FCC and the CJEU thus appear to be ultimately more gradual rather than principled.

\section{Ultra Vires, Take Two: The ECB's Programme and the Paradox of Remediation}

Having declared Weiß ultra vires, the FCC conducts the proportionality test of the PSPP itself. It concludes that the ECB has acted ultra vires because of a "lack of balancing and [a] lack of stating the reasons informing such balancing" (Abwägungs- und Darlegungsausfall). ${ }^{104}$ Hence, with regard to the ECB, the FCC's criticism essentially boils down to procedural shortcomings: First, a lack of balancing, second a lack of motivation with regard to the proportionality of the PSPP programme. ${ }^{105}$ One might wonder if this accusation is justified, given that Advocate General Wathelet reconstructed the ECB's proportionality assessment to a certain extent on the basis of documents submitted to the CJEU and the oral hearing of July 10, 2018. ${ }^{106}$ But even if we assume that the ECB has - against all professional likelihood-not taken into consideration the relevant potential effects in terms of economic policy, such as "the risk of creating real estate and stock market bubbles as well as the economic and social impact on virtually all citizens, who are at least indirectly affected inter alia as shareholders, tenants, real estate owners, savers or insurance policy holders," 107 the procedural shortcomings could still be healed, according to the FCC.

Following the FCC's reasoning, a better motivation could ultimately turn an obvious transgression of competences into a lawful act, ${ }^{108}$ hence categorically transforming an act of economic

\footnotetext{
${ }^{101}$ See again Gärditz, supra note 2, arguing that the FCC should have relied on identity review in order to reject the CJEU's approach, since the (eternal) substantive limits of the Basic Law with regard to European integration would run counter to an approach on the basis of which public authority could be exercised without democratic control and at the same time without strict legal limits and sufficiently effective judicial control mechanisms.

${ }^{102}$ See Sauer, supra note 11 , at 5.

${ }^{103}$ PSPP, at para. 177, where the FCC speaks of a "lack of balancing" (Abwägungsausfall), a term stemming from administrative law doctrine and indicating that the FCC could limit its review to so-called "errors of balancing" (Abwägungsfehler).

${ }^{104} I d$.

${ }^{105} \mathrm{Id}$. at paras. $164-178$.

${ }^{106}$ Opinion of Advocate General Wathelet at para. 140, Case C-493/17, Heinrich Weiss and Others (Oct. 10, 2018).

${ }^{107}$ PSPP, at para. 173 .

${ }^{108} \mathrm{Id}$. at paras. $177,179$.
} 
policy into an act of monetary policy. ${ }^{109}$ One might wonder if such a reasoning isn't methodologically "untenable," to use the expressions of the FCC vis-à-vis the Court of Justice. The fact that the FCC considers the procedural shortcomings to be remediable certainly demonstrates the FCC's willingness to show a way out of the deadlock in which it has maneuvered everyone involved. What it demonstrates most, however, is that there actually was no ultra vires act. It shows that the FCC literally squeezed the case into the framework and path-dependencies of ultra vires review, turning procedural shortcomings into ultra vires acts and potentially vice versa. Again, it becomes apparent that the FCC does not adhere to its own standards of ultra-vires review-manifest violations of competences-but de facto carries out a review of legality.

\section{Contextual Paradoxes}

Beyond the legal dimension, the PSPP decision reveals several paradoxes that relate to the wider context of the decision.

\section{The Rule of Law Paradox}

Several comments point out that the PSPP decision weakens the community of law, given that the decision could serve as a negative role model for other national courts or that it could be misused as an argumentative pattern by autocratic regimes. ${ }^{110}$ One might object, in defence of the FCC, that the PSPP decision in itself certainly cannot be equated with the systematic dismantling of the rule of law in Poland or Hungary ${ }^{111}$ and that avoiding applause from the wrong side cannot be a guiding principle for taking countermajoritarian decisions either. However, as demonstrated above, it is not so much the fact that the FCC declares an act of EU law to be ultra vires in a very exceptional case. What will be remembered is that the FCC chose to do so on the basis of, in part, highly questionable premises and arguments. Herein lies the threat to the community of law. And herein lies also a legitimate reason to ask to what extent the decision may have been influenced by extra-judicial aspects, such as personal preferences for a particular school of economic thought, a general frustration with the CJEU that goes beyond the present case, etc.

\section{The EMU-Reform Paradox}

Having worked through the decision, one might be inclined to ask what it might ultimately be good for. Does it have an overarching benefit? A benefit that could outweigh the open violation of EU law? One main motive is certainly to improve judicial review. As we have already explained, this motive is based on a particular concept of emphasising judicial review in the relationship between the different branches of public authority, a concept which, in a comparative perspective, is rather specific to German constitutional law and cannot be imposed unilaterally on all other Member States. Apart from this, a merit of the decision could be that it may provide an impetus to reform the EMU. ${ }^{112}$ In this respect, a link was established between the Franco-German initiative on a "recovery fund" and the PSPP decision, claiming that the Federal Government might have been pushed by the FCC's decision to change its long-standing course. ${ }^{113}$ However, the plans for the Franco-German initiative had already been prepared before the judgment was pronounced on

\footnotetext{
${ }^{109}$ See also Meier-Beck, supra note 14; Sauer, supra note 11 , at 7.

${ }^{110}$ Keleman et al., supra note 26; Mayer, supra note 6.

${ }^{111}$ Matthias Jestaedt, Keine Handlangerdienste, FAZ (May 14, 2020), https://www.faz.net/einspruch/exklusiv/das-ezburteil-ist-kein-handlangerdienst-fuer-populisten-16770506.html; Komárek, supra note 25.

${ }^{112}$ Bobić \& Dawson, supra note 4.

${ }^{113}$ Mallet et al., The Chain of Events that Led to Germany's Change over Europe's Recovery Fund, FINANCIAL TIMES (May 22, 2020), https://www.ft.com/content/1d8853f4-726d-4c06-a905-ed2f37d25eee.
} 
May 5. Moreover, they were primarily motivated by the COVID-19 crisis and the fear that the EU could fall further apart without solid solidarity measures.

More important in this context is the fact that the case law of the Federal Constitutional Court on EMU can, in substance, hardly serve as an impetus for reforms involving actors other than the courts. What the PSPP decision essentially challenges is the arguably low level of judicial scrutiny. If the ECJ were to take up the FCC's arguments in the future-which seems unlikely at presentEMU policy could be more intensively contested through judicial review (which doesn't necessarily mean an overall increase in legitimacy). However, should it come to reform steps enhancing fiscal and economic policies at EU level and their democratic accountability-inter alia by empowering the European Parliament ${ }^{114}$ - the current case law of the FCC would possibly not work as a catalyst but rather as a brake for the EMU reform. The FCC focuses on securing national democracy. Hence, the budgetary autonomy of the Bundestag is of particular sensitivity for the FCC. ${ }^{115}$ In contrast, the FCC has little confidence in the ability of the European Parliament to generate sufficient democratic legitimacy at the European level. ${ }^{116}$

The same concerns arise in relation to projects involving shared debt or functional equivalents. The envisaged "Recovery Fund"-based on Articles 311 and 122 II TFEU according to current planning-could also end up before the FCC in the future, either within the framework of ultra vires review or within the framework of identity review. ${ }^{17}$ At present, there are no substantive grounds whatsoever to suggest that the Recovery Fund could constitute an ultra vires act with regard to Art. 310 TFEU or that it could violate German constitutional identity with regard to the budgetary autonomy of the Bundestag. However, one should not underestimate the scope of interpretation available to the FCC in interpreting the constitutional core principles of the Basic Law, nor the preventive effect of its case law. A politician would certainly want to avoid even entering the grey zones in which there might be a risk of violating constitutional identity, for such a violation (if ultimately established by the FCC) could not even be overcome by a constitutional amendment, but at best by a new constitution.

\section{The Democracy Paradox}

The third contextual paradox relates to the principle of democracy and lies in the potential circumvention of the democratic process by means of an actio popularis. In trying to secure the essence of the principle of democracy the FCC resorts to methods that run the risk of circumventing precisely that objective. The FCC reveals a highly questionable conception of democracy $^{118}$ when it essentially empowers individuals by means of a judicial actio popularis to demand from the elected representatives of the people to take legally non-specifiable "steps" vis-à-vis the ECB.

Also in this respect it is worth re-reading the two dissenting opinions on OMT. They reveal that the majority within the FCC's Second Senate was, and perhaps still is, concerned with ensuring the "public nature of the parliamentary process." 119 In this light, the PSPP decision appears to be another attempt to take the discussion on the ECB's policy into the parliament. As in the

\footnotetext{
${ }^{114}$ For reform proposals aiming at strengthening the democratic decision-making processes, see INGOLF PERNICE ET AL., A Democratic Solution to the Crisis 104 (2012).

${ }^{115}$ See, e.g., Bundesverfassungsgericht [BVerfG] [Federal Constitutional Court], Case No. 2BvR 987/10, (Sept. 7, 2011), http://www.bverfg.de/e/rs20110907_2bvr098710en.html; Bundesverfassungsgericht [BVerfG] [Federal Constitutional Court], Case No. 2 BvR 1390/12, (Mar. 18, 2014), http://www.bverfg.de/e/rs20140318_2bvr139012en.html.

${ }^{116}$ Lisbon Judgement, at para. 286 et seq.

${ }^{117}$ The fact that the FCC rejects a violation of constitutional identity in PSPP with regard to the scheme for the allocation of risk between the national central banks ( PSPP, at paras. 222-228) does not imply that the FCC would accept reform steps that would result in any form of debt collectivization.

${ }^{118}$ And also a highly questionable conception of separation of powers.

${ }^{119}$ Gerhardt, supra note 33, at para 20 (“Öffentlichkeit des parlamentarischen Prozesses").
} 
OMT-saga, however, it is rather the FCC's courtroom that is becoming a substitute for the political arena and is supposed to fulfil a function of "democratic compensation," as a member of the FCC put it in his academic writings. ${ }^{120}$ Some scholars even conceive the actio popularis as a "constitutional-complaint-plebiscite" compensating for the lack of direct democracy at the federal level. ${ }^{121}$ However, a constitutional court is hardly capable of fulfilling this function already because of its institutional setting and its entirely different role. ${ }^{122}$ One should also not forget that an everincreasing expansion of the actio popularis might turn out to have an anti-parliamentarian tendency. In the words of former Judge Lübbe-Wolff, it appears as an "anomaly of questionable democratic character" if several German judges who invoke the German interpretation of the principle of democracy and the limits which follow from it "make a decision with incalculable consequences for the operating currency of the euro zone and the national economies depending on it." 123

\section{The Community Paradox}

A final paradox relates to the legal community addressed by the decision. The decision affects many, but is fully accessible only to some. It is framed in terms of the law of a single Member State, but at the same time concerns all others by virtue of its scope and its content. While an ultra vires decision is relevant not only to the legal community in the respective Member State, but also to the legal community abroad, it creates a structural asymmetry by framing a European legal question largely in terms of national law. Despite all the welcome efforts of national constitutional courts, including the FCC, to deliver translations of their decisions, the hurdle to understanding such decisions remains particularly high for lawyers who have not been socialised in the respective national legal system. ${ }^{124}$ The legal discourses in Europe are still largely fragmented, even as regards EU law. ${ }^{125}$ Certainly, there are important transnational communities and networks. There are also foreign colleagues who know the EU-related case law of national constitutional courts far better than many domestic lawyers. And there are excellent journals, opening up the national discourse to a wider audience. And yet the fact remains that understanding a decision such as that of May 5 is a particular challenge. Anyone who has ever seriously attempted to work in the field of comparative constitutional law might share the experience that quite a number of parameters can lead to misunderstandings, be it terminological nuances, procedural specificities, doctrinal premises, the style of reasoning, the institutional architecture, the constitutional culture, or the political context. This is not to say that lawyers socialised in the German legal system, including myself, would necessarily understand what the FCC says, let alone that they would agree in their analysis. But the fact that a decision such as that of May 5 frames a European question largely in terms of German constitutional law makes it particularly challenging for lawyers outside Germany. In return, these challenges should also not serve as a (tacit) excuse for completely ignoring the national constitutional discourse in the analysis of such a decision.

All in all, the PSPP-decision which affects many, but is fully accessible only to some, is a prime example of why the CJEU would have to be invented if it didn't already exist: An institution uniting different legal cultures, speaking and understanding the language of all participants on a basis of equality and ensuring equal access to court in procedural as well as in intellectual terms.

\footnotetext{
${ }^{120}$ Peter-Michael Huber, Article 19 IV GG, in GG Kommentar para. 352 (7th ed., Hermann von Mangoldt, Friedrich Klein, \& Christian Starck eds., 2018) (“demokratiespezifische Ventil- oder Kompensationsfunktion”).

${ }^{121}$ Wolfgang Kahl, Bewältigung der Staatsschuldenkrise unter Kontrolle des Bundesverfassungsgerichts, 128 DEUTSCHES VERWALTUNGSBLATT [DVBL] 197, 207 (2013).

${ }^{122}$ See already in detail Wendel, supra note 34 , at para. 282 et seq.

${ }^{123}$ Lübbe-Wolff, supra note 33 , at para. 18.

${ }^{124} \mathrm{Cf}$. Ziller, supra note 8.

${ }^{125}$ See Daniel Thym, The Limits of Transnational Scholarship on EU Law. A View from Germany (May 27, 2016), EUI WORKING PAPER LAW 2016/14, https://ssrn.com/abstract=2785668.
} 


\section{E. Conclusion and Outlook}

To conclude, the PSPP judgment is a highly paradoxical decision. Despite the FCC's doubtlessly well-intentioned efforts to secure a sufficient level of judicial review, the decision suffers, according to our reading, of considerable shortcomings and inconsistencies. It does not provide a solid basis under the FCC's own standards to declare the CJEU's Weiß judgment and the ECB's PSPP ultra vires. A positive effect could at least be that the ECB makes its decisions or deliberations somewhat more transparent. Nevertheless, it is to be hoped that this type of ultra vires decision will not set a precedent across the EU. 